\title{
Alternation of Insecticidal Sprays for the Management of Thrips (Thrips tabaci Lindeman) and Whitefly (Bemisia tabaci Gennadius) Pest of Bt Cotton in Malwa Region of Madhya Pradesh
}

\author{
Bhavna Verma*, Nikki Bhardwaj, S.B. Singh and Manorama Sharma \\ RVSKVV, College of Agriculture, Indore, India \\ *Corresponding author
}

\begin{tabular}{|l|}
\hline Ke y w o r d s \\
Alternation; \\
Efficacy; \\
Insecticides; Bt \\
cotton; Thrips; \\
Whitefly
\end{tabular}

\section{Introduction}

Cotton (Gossypium sp.) is an important Kharif cash and fibre crop of India known as the "white gold", grown in almost all parts of the country. Nimar and Malwa Plateau is the major $B t$ cotton producing region of Madhya Pradesh. Among the sucking insect pests
The experiment was carried out during kharif 2014 at College of Agriculture, Indore under All India Coordinated Cotton Improvement Project in Randomized Block Design (RBD) with eight treatments and three replications on Bt cotton hybrid NCS 927, sown on $27^{\text {th }}$ July with $0.6 \times 0.6 \mathrm{~m}$ spacing. The recommended agronomical practices were adopted properly. Each treatment was prepared for alternate use of two insecticides during six sprays. The spraying was done at 10 days interval with 500 litre water per hectare, sprayed by knapsack sprayer fitted with a duromist nozzle. These treatments were marked as $\mathrm{T}_{1-}$ Imidacloprid (70\%WG) @ 24.5 gai/ha \& Oxydmeton methyl (25\%EC) @ 250 gai/ha, $\mathrm{T}_{2-}$ Thiaclorprid $(21.7 \% \mathrm{SC})$ @ 30 gai/ha \& Dimethoate $(30 \% \mathrm{EC}) @ 250 \mathrm{gai} / \mathrm{ha}, \mathrm{T}_{3-}$ Imidacloprid (17.8\%SL) @ 25 gai/ha \& Acephate $(75 \% \mathrm{SP})$ @ 250 gai $/ \mathrm{ha}, \mathrm{T}_{4-}$ Imidacloprid (30.5\%SC) @ 26.25 gai/ha \& Thiamethoxam (25\%WG) @ 37.5 gai/ha, $\mathrm{T}_{5-}$ Spiromesifen (22.9\%SC) @ 144 gai/ha \& Deltamethrin (2.8\%EC) @ 15 gai/ha, T 6 -Fipronil (5\%SC)@100 gai/ha \& Lambdacyhalothrin (4.9\%EC) @ 15 gai/ha, $\mathrm{T}_{7-}$ Acetamiprid

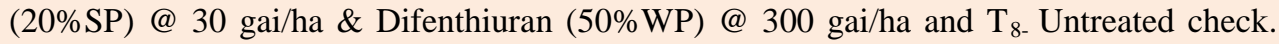
Except third spray, in all the sprays $\mathrm{T} 5$ reduced maximum thrips population and found at par with T6. The highest population reduction was also noted in T5 (77.78\%) followed by T6- (76.94\%). The population of whitefly was lowest after each spray in T2- and showed no significant difference with T3 except in $6^{\text {th }}$ spray. The similar trend was observed in population reduction also in T2 $(76.69 \%)$ and T3 $(72.20 \%)$. 
reported from different parts of cotton fields in Punjab that cripples the growth of cotton plant and this has resulted in reduction of $B t$ cotton yield. Transgenic cultivars were more susceptible to thrips infestation as compared to conventional genotypes (Saif-ur-Rehman $e t$ al., 2013).

The continuous cultivation of $B t$ cotton increased the activities of sucking pests. In present scenario a numbers of sprays of various insecticides are required to manage these insect pests. The continuous and repeated application of various insecticides has created many fold resistance against insecticides (Singh and Jaglan, 2005 and Sayyed et al., 2011). To avoid the resistance against insecticides present study was planned to assess the efficacy of insecticides use in alternation in each spray.

Sucking pests viz., aphids (Aphis gossypii Glover), leaf hopper (Amrasca biguttula biguttula Ishida), whiteflies (Bemisia tabaci Gennadius) and thrips, (Thrips tabaci Lindeman) are deleterious to the cotton crop growth and development (Vennila et al., 2000). The estimated loss due to sucking pest's complex was up to 21.20 per cent (Dhawan et al., 1988). Sucking pests viz., aphids (Aphis gossypii Glover), leaf hopper (Amrasca biguttula biguttula Ishida), whiteflies (Bemisia tabaci Gennadius) and thrips, (Thrips tabaci Lindeman) are deleterious to the cotton crop growth and development (Vennila et al., 2000). The estimated loss due to sucking pest's complex was up to 21.20 per cent (Dhawan et al., 1988). Sucking pests viz., aphids (Aphis gossypii Glover), leaf hopper (Amrasca biguttula biguttula Ishida), whiteflies (Bemisia tabaci Gennadius) and thrips, (Thrips tabaci Lindeman) are deleterious to the cotton crop growth and development (Vennila et al., 2000). The estimated loss due to sucking pest's complex was up to 21.20 per cent (Dhawan et al.,
1988). Sucking pests viz., aphids (Aphis gossypii Glover), leaf hopper (Amrasca biguttula biguttula Ishida), whiteflies (Bemisia tabaci Gennadius) and thrips (Thrips tabaci Lindeman) are deleterious to the cotton crop growth and development (Vennila et al., 2000). The estimated loss due to sucking pest's complex was up to 21.20 per cent (Dhawan et al., 1988).

\section{Materials and Methods}

The experiment was conducted during kharif 2014 at College of Agriculture, Indore under All India Coordinated Cotton Improvement Project in Randomized Block Design (RBD) with eight treatments including untreated check and three replications. The Bt cotton hybrid NCS 927 was sown on $27^{\text {th }}$ July with the spacing of $0.6 \times 0.6 \mathrm{~m}$. All the recommended agronomical practices were adopted for the proper growth of crop. Application of continuous six sprays was planned with two insecticides in each treatment for alternate use at 10 days interval with 500 litre water per hectare, sprayed by knapsack sprayer fitted with a duromist nozzle. These treatments were marked as $\mathrm{T}_{1 \text { - }}$ Imidacloprid (70\%WG) @ 24.5 gai/ha \& Oxydmeton methyl (25\%EC) @ 250 gai/ha, T2- Thiaclorprid $(21.7 \% \mathrm{SC})$ @ 30 gai/ha \& Dimethoate (30\%EC) @ 250 gai/ha, T 3 Imidacloprid (17.8\%SL) @ 25 gai/ha \& Acephate (75\%SP) @ 250 gai/ha, $\mathrm{T}_{4-}$ Imidacloprid $(30.5 \% \mathrm{SC}) @ 26.25$ gai $/ \mathrm{ha} \&$ Thiamethoxam (25\%WG) @37.5 gai/ha, T5Spiromesifen (22.9\%SC) @ 144 gai/ha \& Deltamethrin (2.8\%EC) @ 15 gai/ha, $\mathrm{T}_{6-}$ Fipronil (5\%SC) @ 100 gai/ha \& Lambdacyhalothrin (4.9\%EC) @ 15 gai/ha, T 7. Acetamiprid (20\%SP) @ 30 gai/ha \& Difenthiuran (50\%WP) @ 300 gai/ha and $\mathrm{T}_{8-}$ Untreated check. Observations were recorded at pre spraying and post spraying after 10 days in each spray on five randomly selected tagged plants per plot. Thrips and whitefly 
population were counted on 5 tagged plants per plot with 2 lower, 2 middle and 1 upper leaves per plant and averaged as pest population $/ 5$ leaves. The data was averaged and analyzed statistically and presented in table. Finally the overall population reduction was calculated based on pretreatment observation and observation of last spray.

\section{Results and Discussion}

\section{Thrips}

The findings revealed that initially thrips population (Table 1 and Fig. 1) ranged from 31.62 to 34.57 per 5 leaves. After first and second spray the highest efficacy with least insect population was noted in T5Spiromesifen $(22.9 \%$ SC) @ 144 gai/ha \& Deltamethrin $(2.8 \%$ EC) @ 15 gai/ha (18.64 and 17.32) and found at par with T6- Fipronil (5\%SC)@100 gai/ha \& Lambdacyhalothrin (4.9\%EC) @15 gai/ha (19.74 and 117.44) in both sprays and in T4- Imidacloprid (30.5\%SC)@26.25 gai/ha \& Thiamethoxam (25\%WG) @ 37.5 gai/ha (21.13) in first spray. In third spray T6 (13.67) ranked first but found at par with T5 (15.47). In fourth (11.27), fifth (8.63) and sixth spray (7.68) treatment T5 exhibited no significant difference with T6 as 12.15, 8.74 and 7.89 thrips population, respectively. Finally based on overall population reduction treatment $\mathrm{T} 5$ showed highest population reduction (77.78\%) followed by T6 (76.94\%), T2Thiaclorprid $(21.7 \% \mathrm{SC})$ @ 30 gai/ha \& Dimethoate (30\%EC) @ 250 gai/ha (71.63\%), T1- Imidacloprid (70\%WG) @ 24.5 gai/ha \& Oxydmeton methyl (25\%EC) @ 250 gai/ha (70.63\%), T3- Imidacloprid (17.8\%SL) @ 25 gai/ha \& Acephate (75\%SP) @ 250 gai/ha (67.32\%) (67.32\%), T7- Acetamiprid (20\%SP) @ 30 gai/ha \& Difenthiuran (50\%WP) @ 300 gai/ha (64.81\%) and T4Imidacloprid (30.5\%SC) @ 26.25 gai/ha \& Thiamethoxam (25\%WG) @ 37.5 gai/ha
(64.11\%). Varghese and Mathew (2013) reported that spiromesifen at $20 \mathrm{~g}$ a.i. ha ${ }^{-1}$ was found to be effective against chilli thrips reduced the leaf curling symptom and safest insecticide against natural enemies. Bretschneider et al., (2003) stated that spiromesifen is effective to suppress some species of thrips such as Scirtothrips dorsalis, Thrips palmi and Thrips tabaci in vegetables and found active against juvenile stages of insect. Stanislav et al., (2007) found the efficacy of deltamethrin against Thrips tabaci on white cabbage by one spraying which was sufficient to reduce leaf damage below the higher (more tolerant) threshold, but three sprayings were needed to reduce leaf damage below the lower (more stringent) threshold.

Further, Saner et al., (2013) expressed that thrip population was promisingly suppressed by fipronil $80 \mathrm{WG}$, followed by fipronil $5 \mathrm{SC}$ in cotton. Similarly Kumar et al., (2013) found the bio-efficacy of fipronil against thrips, Thrips tabaci on cotton. Dongarjal, et al., (2018) assessed that fipronil was statistically superior over other treatments against pomegranate thrips. Kadam and Dethe (2002) and Jadhav et al., (2004) reported the highest efficacy of fipronil 5\% SC @ 40 to 60 $\mathrm{g}$ a.i./ha and $100 \mathrm{~g}$ a.i./ha against chilli thrips. Singh et al., (2013) observed that fipronil 5\% SC and lambda-cyhalothrin $4.9 \%$ SC were the most effective insecticide in reducing the thrips population in onion. Further, Anonymous, (2006) with the application of fipronil @ $1.5 \mathrm{ml} / \mathrm{l}$ and Pokharkar et al., (2011) with 0.075 per cent spray of fipronil, found significantly superior effect in suppressing onion thrips population. Kadam (2012) reported the better efficacy of lambda cyhalothrin against pomegranate thrips incidence with highest yield. The findings of these researchers against thrips in cotton and other crops are in close conformity with the present investigation. 


\section{Whitefly}

The present study exhibited pretreatment population of whitefly (Table 2 and Fig. 2) in the range of 33.06 to 35.12 per 5 leaves. After first spray highest population reduction was noted in each treatment but in rest of the sprays population decreased slightly with little margin.

Table.1 Efficacy of insecticides against thrips in $B t$ cotton

\begin{tabular}{|c|c|c|c|c|c|c|c|c|c|}
\hline \multirow{3}{*}{$\begin{array}{l}\text { Treat } \\
\text { ments }\end{array}$} & \multirow{3}{*}{$\begin{array}{l}\text { Dosage } \\
\text { g.a.i./ha }\end{array}$} & \multirow{3}{*}{$\begin{array}{l}\text { Pre- } \\
\text { treat } \\
\text { ment }\end{array}$} & \multicolumn{6}{|c|}{ Thrips population /5 leaves } & \multirow{3}{*}{$\begin{array}{c}\text { Overall } \\
\text { Population } \\
\text { reduction } \\
(\%)\end{array}$} \\
\hline & & & \multicolumn{6}{|c|}{10 Days After Spray } & \\
\hline & & & $1^{\text {st spray }}$ & $\begin{array}{l}2_{\text {spray }}^{\text {nd }} \\
\text {. }\end{array}$ & $3^{\text {rd spray }}$ & $4^{\text {th spray }}$ & $5^{\text {th spray }}$ & $6^{\text {th spray }}$ & \\
\hline T1 & 24.5 and 250 & $\begin{array}{l}32.83 \\
(5.73)\end{array}$ & $\begin{array}{l}23.12 \\
(4.86)\end{array}$ & $\begin{array}{l}18.38 \\
(4.35)\end{array}$ & $\begin{array}{l}16.69 \\
(4.15)\end{array}$ & $\begin{array}{l}14.73 \\
(3.90)\end{array}$ & $\begin{array}{l}11.29 \\
(3.43)\end{array}$ & $\begin{array}{l}9.64 \\
(3.18)\end{array}$ & 70.63 \\
\hline \multirow[t]{2}{*}{$\mathbf{T} 2$} & \multirow[t]{2}{*}{30.0 and 250} & 31.62 & 22.17 & 19.67 & 17.67 & 13.29 & 10.67 & 8.97 & 71.63 \\
\hline & & $(5.67)$ & $(4.76)$ & $(4.49)$ & $(4.26)$ & $(3.71)$ & $(3.34)$ & $(3.08)$ & \\
\hline \multirow[t]{2}{*}{ T3 } & \multirow[t]{2}{*}{25.0 and 250} & 31.73 & 21.91 & 19.32 & 16.53 & 12.98 & 11.36 & 10.37 & 67.32 \\
\hline & & $(5.68)$ & $(4.73)$ & $(4.45)$ & $(4.13)$ & $(3.67)$ & $(3.44)$ & $(3.30)$ & \\
\hline \multirow[t]{2}{*}{ T4 } & \multirow[t]{2}{*}{26.25 and 37.5} & 33.24 & 21.13 & 19.79 & 18.73 & 15.69 & 13.47 & 11.93 & 64.11 \\
\hline & & $(5.81)$ & $(4.65)$ & $(4.50)$ & $(4.39)$ & $(4.02)$ & $(3.74)$ & $(3.53)$ & \\
\hline \multirow[t]{2}{*}{ T5 } & \multirow[t]{2}{*}{144 and 15.0} & 34.57 & 18.64 & 17.32 & 15.47 & 11.27 & 8.63 & 7.68 & 77.78 \\
\hline & & $(5.92)$ & $(4.37)$ & $(4.22)$ & $(4.00)$ & $(3.43)$ & $(3.02)$ & $(2.86)$ & \\
\hline \multirow[t]{2}{*}{ T6 } & \multirow[t]{2}{*}{100 and 15.0} & 34.22 & 19.74 & 17.44 & 13.67 & 12.15 & 8.74 & 7.89 & 76.94 \\
\hline & & $(5.85)$ & $(4.50)$ & $(4.24)$ & (3.76) & $(3.56)$ & (3.04) & $(2.90)$ & \\
\hline \multirow[t]{2}{*}{ T7 } & \multirow[t]{2}{*}{30.0 and 300} & 33.40 & 22.62 & 21.69 & 19.28 & 16.74 & 13.17 & 11.78 & 64.73 \\
\hline & & $(5.78)$ & $(4.81)$ & $(4.71)$ & $(4.45)$ & $(4.15)$ & $(3.70)$ & $(3.50)$ & \\
\hline \multirow[t]{2}{*}{ T8 } & \multirow[t]{2}{*}{--- } & 33.48 & 35.09 & 38.6 & 39.27 & 47.43 & 47.23 & 49.12 & - \\
\hline & & $(5.78)$ & $(5.97)$ & $(6.25)$ & $(6.31)$ & $(6.92)$ & $(6.91)$ & $(7.04)$ & \\
\hline S Em \pm & & - & 0.10 & 0.06 & 0.08 & 0.07 & 0.08 & 0.08 & \\
\hline $\begin{array}{l}\text { CD at } \\
5 \%\end{array}$ & & NS & 0.30 & 0.17 & 0.24 & 0.21 & 0.24 & 0.25 & \\
\hline CV \% & & - & 7.51 & 5.04 & 6.45 & 5.64 & 7.15 & 7.01 & \\
\hline
\end{tabular}

The values in parentheses are square root transformed values.

DAS = Days after spray.

Treatments:

$\mathrm{T}_{1-}$ Imidacloprid (70\%WG) @ 24.5 gai/ha \& Oxydmeton methyl (25\%EC) @ 250 gai/ha,

$\mathrm{T}_{2-}$ Thiaclorprid (21.7\% SC) @ 30 gai/ha \& Dimethoate (30\%EC) @ 250 gai/ha,

$\mathrm{T}_{3-}$ Imidacloprid (17.8\% SL) @ 25 gai/ha \& Acephate $(75 \% \mathrm{SP}) @ 250 \mathrm{gai} / \mathrm{ha}$,

$\mathrm{T}_{4-}$ Imidacloprid $(30.5 \% \mathrm{SC}) @ 26.25 \mathrm{gai} / \mathrm{ha} \&$ Thiamethoxam $(25 \% \mathrm{WG}) @ 37.5 \mathrm{gai} / \mathrm{ha}$,

$\mathrm{T}_{5-}$ Spiromesifen $(22.9 \% \mathrm{SC})$ @ 144 gai/ha \& Deltamethrin $(2.8 \% \mathrm{EC}) @ 15$ gai/ha,

$\mathrm{T}_{6}$ Fipronil (5\% SC) @ 100 gai/ha \& Lambdacyhalothrin (4.9\%EC) @ 15 gai/ha,

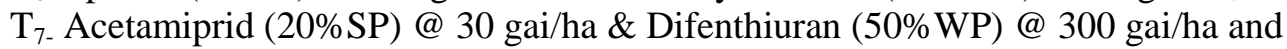

$\mathrm{T}_{8-}$ Untreated check. 
Table.2 Efficacy of insecticide against whitefly in $B t$ cotton

\begin{tabular}{|c|c|c|c|c|c|c|c|c|c|}
\hline \multirow{3}{*}{$\begin{array}{c}\text { Treatm } \\
\text { ents }\end{array}$} & \multirow{3}{*}{$\begin{array}{l}\text { Dosage } \\
\text { g.a.i./ha }\end{array}$} & \multirow{3}{*}{$\begin{array}{l}\text { Pre- } \\
\text { treat } \\
\text { ment }\end{array}$} & \multicolumn{6}{|c|}{ Whitefly population /5 leaves } & \multirow{3}{*}{$\begin{array}{c}\text { Overall } \\
\text { Population } \\
\text { reduction } \\
(\%)\end{array}$} \\
\hline & & & \multicolumn{6}{|c|}{10 Days After Spray } & \\
\hline & & & $\mathbf{1}_{\text {spray }}^{\text {st }}$ & $\underset{\text { spray }}{2^{\text {nd }}}$ & $3^{\text {rd spray }}$ & $4^{\text {th spray }}$ & $5^{\text {th spray }}$ & $6^{\text {th spray }}$ & \\
\hline \multirow[t]{2}{*}{ T1 } & \multirow[t]{2}{*}{24.5 and 250} & 35.12 & 19.72 & 15.82 & 14.81 & 13.45 & 12.31 & 11.62 & 66.91 \\
\hline & & $(5.97)$ & $(4.50)$ & $(4.04)$ & $(3.91)$ & $(3.73)$ & $(3.58)$ & $(3.48)$ & \\
\hline \multirow[t]{2}{*}{$\mathbf{T 2}$} & \multirow[t]{2}{*}{30.0 and 250} & 33.21 & 16.95 & 15.14 & 12.13 & 11.44 & 9.58 & 7.74 & 76.69 \\
\hline & & $(5.81)$ & $(4.18)$ & $(3.95)$ & $(3.55)$ & $(3.46)$ & $(3.17)$ & $(2.87)$ & \\
\hline \multirow[t]{2}{*}{ T3 } & \multirow[t]{2}{*}{25.0 and 250} & 33.06 & 17.52 & 15.78 & 13.08 & 12.16 & 11.24 & 9.19 & 72.20 \\
\hline & & $(5.75)$ & $(4.24)$ & $(4.03)$ & $(3.69)$ & $(3.56)$ & $(3.43)$ & $(3.11)$ & \\
\hline \multirow[t]{2}{*}{ T4 } & \multirow[t]{2}{*}{26.25 and 37.5} & 35.32 & 18.12 & 16.72 & 16.96 & 15.08 & 12.96 & 10.96 & 68.97 \\
\hline & & $(5.98)$ & $(4.32)$ & $(4.27)$ & $(4.18)$ & $(3.95)$ & $(3.67)$ & $(3.39)$ & \\
\hline \multirow[t]{2}{*}{ T5 } & \multirow[t]{2}{*}{144 and 15.0} & 35.18 & 20.15 & 16.78 & 14.08 & 13.23 & 11.74 & 9.82 & 72.08 \\
\hline & & (5.97) & $(4.54)$ & (4.16) & $(3.82)$ & $(3.71)$ & $(3.50)$ & $(3.21)$ & \\
\hline \multirow[t]{2}{*}{ T6 } & \multirow[t]{2}{*}{100 and 15.0} & 34.45 & 19.12 & 18.21 & 16.86 & 13.44 & 11.35 & 10.67 & 69.02 \\
\hline & & $(5.87)$ & $(4.43)$ & $(4.33)$ & $(4.17)$ & $(3.73)$ & $(3.44)$ & $(3.34)$ & \\
\hline \multirow[t]{2}{*}{$\mathbf{T 7}$} & \multirow[t]{2}{*}{30.0 and 300} & 33.52 & 21.18 & 19.91 & 18.91 & 16.09 & 13.92 & 11.33 & 66.19 \\
\hline & & $(5.79)$ & $(4.66)$ & $(4.52)$ & $(4.41)$ & $(4.07)$ & $(3.80)$ & $(3.44)$ & \\
\hline \multirow[t]{2}{*}{ T8 } & \multirow[t]{2}{*}{---} & 35.04 & 39.45 & 43.46 & 44.42 & 45.58 & 49.39 & 54.2 & - \\
\hline & & (5.92) & $(6.32)$ & $(6.63)$ & $(6.70)$ & $(6.79)$ & $(7.08)$ & $(7.40)$ & \\
\hline S Em \pm & & - & 0.06 & 0.09 & 0.09 & 0.08 & 0.09 & 0.06 & \\
\hline $\begin{array}{l}\text { CD at } \\
5 \%\end{array}$ & & NS & 0.19 & 0.26 & 0.28 & 0.23 & 0.26 & 0.18 & \\
\hline $\mathrm{CV} \%$ & & - & 5.04 & 7.14 & 7.19 & 6.53 & 7.62 & 5.39 & \\
\hline
\end{tabular}

The values in parentheses are square root transformed values.

DAS $=$ Days after spray.

Treatments detail:

$\mathrm{T}_{1-}$ Imidacloprid (70\%WG) @ 24.5 gai/ha \& Oxydmeton methyl (25\%EC) @ 250 gai/ha,

$\mathrm{T}_{2}$-Thiaclorprid (21.7\% SC) @ 30 gai/ha \& Dimethoate (30\%EC) @ 250 gai/ha,

$\mathrm{T}_{3-}$ Imidacloprid (17.8\% SL) @ 25 gai/ha \& Acephate (75\% SP) @ 250 gai/ha,

$\mathrm{T}_{4-}$ Imidacloprid (30.5\% SC) @ 26.25 gai/ha \& Thiamethoxam (25\%WG) @ 37.5 gai/ha,

$\mathrm{T}_{5-}$ Spiromesifen (22.9\% SC) @ 144 gai/ha \& Deltamethrin (2.8\%EC) @ 15 gai/ha,

$\mathrm{T}_{6}$ Fipronil (5\%SC) @ 100 gai/ha \& Lambdacyhalothrin (4.9\%EC) @ 15 gai/ha,

$\mathrm{T}_{7 .}$ Acetamiprid (20\%SP) @ 30 gai/ha \& Difenthiuran (50\%WP) @ 300 gai/ha and

$\mathrm{T}_{8 \text { - Untreated check. }}$ 
Fig.1 Efficacy of insecticides against thrips in Bt cotton

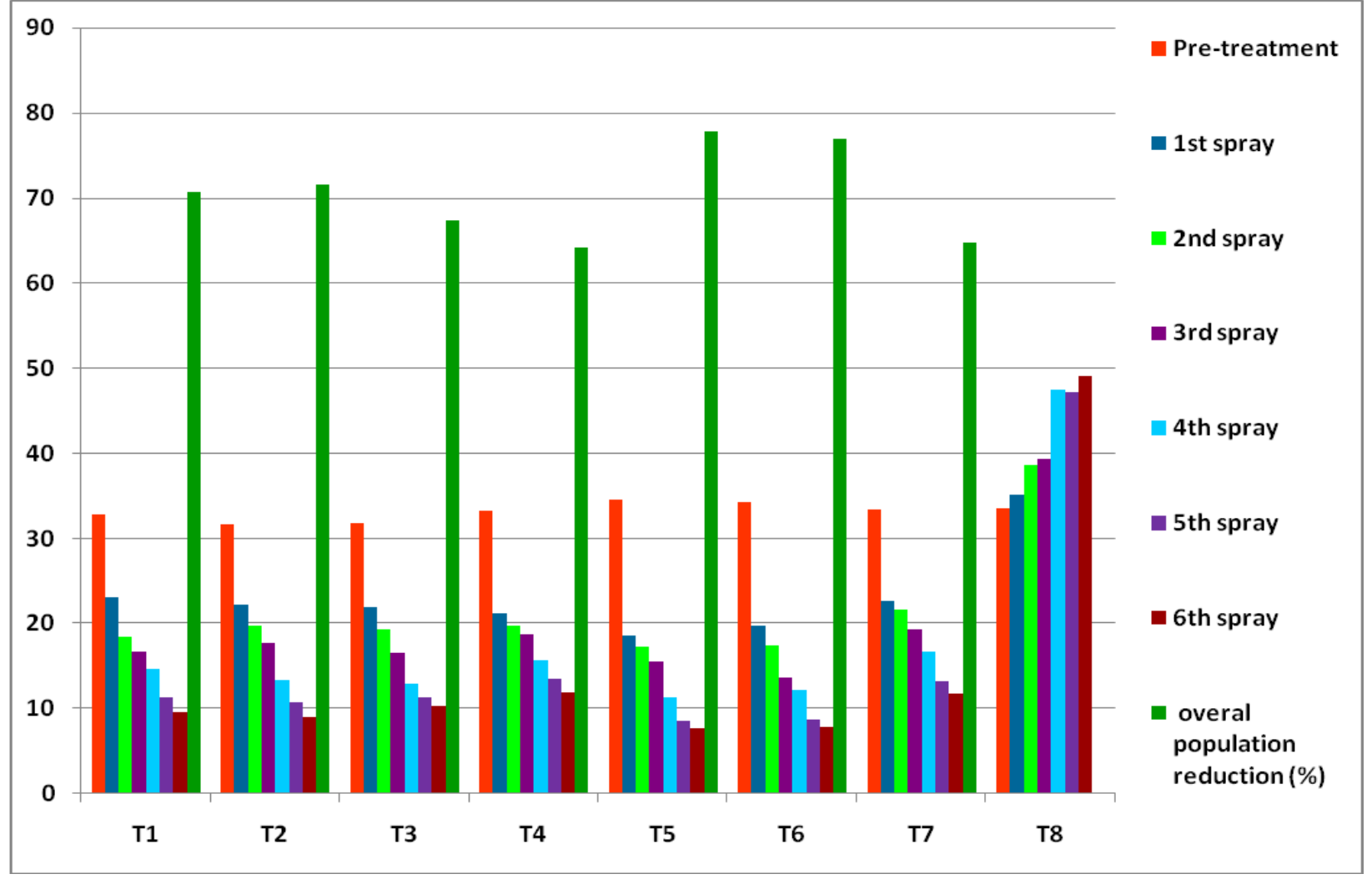

Fig.2 Efficacy of insecticide against whitefly in Bt cotton

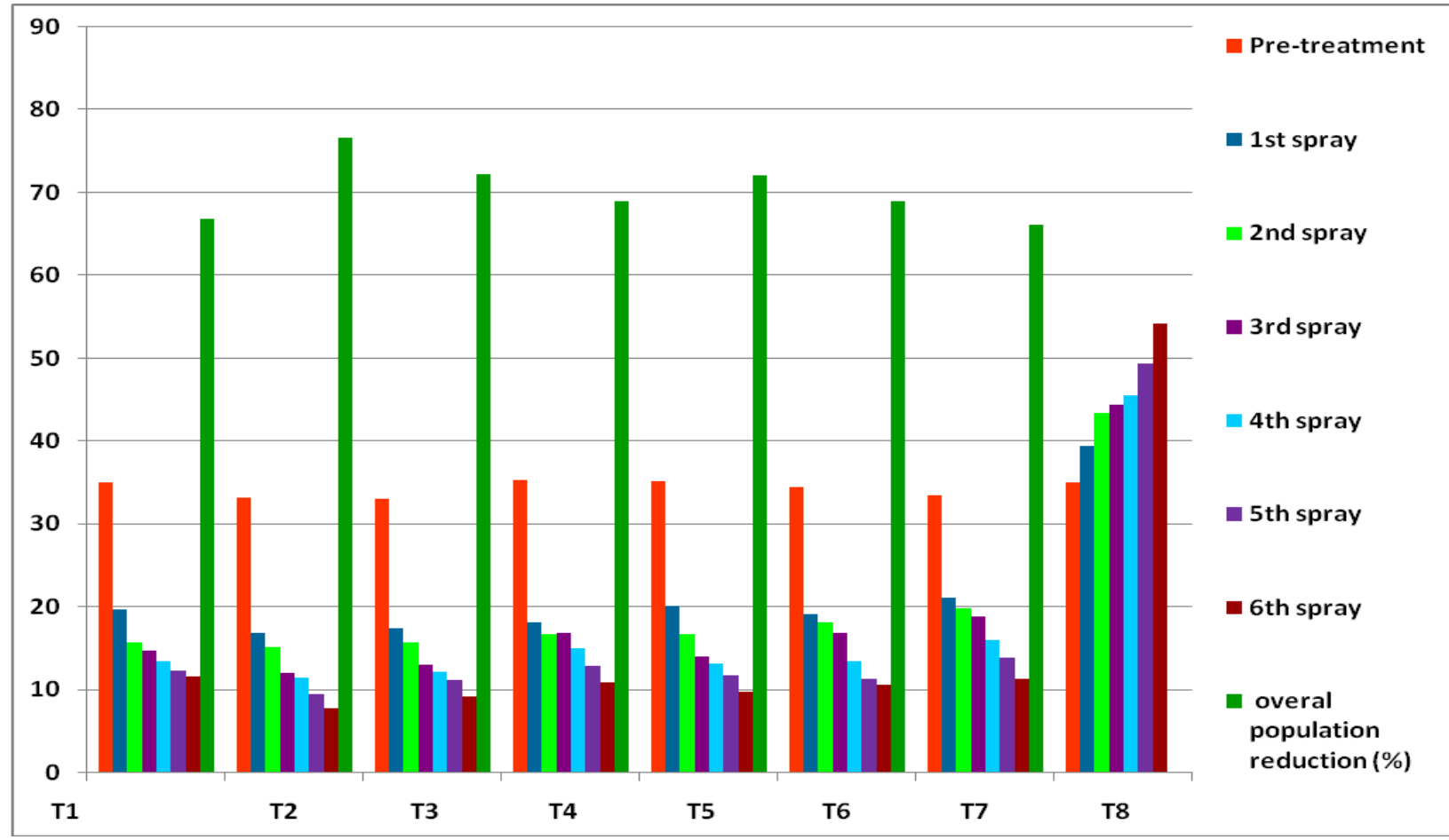


In each spray the lowest pest population was noted in T2- Thiaclorprid $(21.7 \% \mathrm{SC}) @ 30$ gai/ha \& Dimethoate (30\%EC) @ 250 gai/ha as $16.95,15.14,12.13,11.44,9.54$ and 7.74 per 5 leaves, respectively, showed highest efficacy. Treatment T3- Imidacloprid (17.8\%SL) @ 25 gai/ha \& Acephate $(75 \% \mathrm{SP})$ @ 250 gai/ha exhibited no significant difference with T2 except in $6^{\text {th }}$ spray.

The overall population reduction was also recorded highest in T2 $(76.69 \%)$ followed by T3 (72.20\%), T5- Spiromesifen (22.9\%SC) @ 144 gai/ha \& Deltamethrin (2.8\%EC) @ 15 gai/ha (69.02\%), T6- Fipronil (5\%SC) @ 100 gai/ha \& Lambdacyhalothrin (4.9\%EC) @ 15 gai/ha (76.20\%), (69.02\%), T4- Imidacloprid (30.5\%SC) @ 26.25 gai/ha \& Thiamethoxam (25\%WG) @ 37.5 gai/ha (68.97\%), T1Imidacloprid (70\%WG) @ 24.5 gai/ha \& Oxydmeton methyl (25\%EC) @ 250 gai/ha $(66.91 \%)$ and T7- Acetamiprid (20\%SP) @ 30 gai/ha \& Difenthiuran (50\%WP) @ 300 gai/ha (66.19\%). The higher efficacy of thiacloprid and imidacloprid compared to conventional insecticides against cotton whitefly was reported by Ahmad et al., (2014). Shivanna et al., (2011) observed that dimethoate alone was most effective against cotton whitefly at three and seven days after spraying. Kumar et al., (2017) revealed that imidacloprid 17.8 SL @ $100 \mathrm{ml} / \mathrm{ha}$, was effective insecticide in reducing the population of whitefly, Bemisia tabaci in brinjal with higher cost benefit ratio (1:12.90). Amjad et al., (2009) reported that Confidor (imidacloprid) was the most effective insecticides for whitefly, up to seven days in cotton. Babar et al., (2013) showed mortality of cotton whitefly $(76 \%) 72$ hours after spray by Imidacloprid 200SL. Kalyan et al., (2012) stated that imidacloprid 70 WG @ 50 a.i./ha and acephate 75 SP @ 500 a.i./ha effectively controlled the population of whitefly and gave significantly higher seed cotton yield over to untreated check and standard check. Further, Sahito et al., (2015) found the efficacy of acephate with the reduction of whitefly population up to 60 per cent. The results of these researchers are in the line of agreement and supported the present findings.

\section{References}

Aheer, GM, Ghani A. and Ali A.1999. Population of whitefly, Bemisia tabaci (Genn.) and its natural enemies on cotton crop at Bahawalpur. Pak. Entomol., 21:47-49

Ahmed, S., Nisar, M. S. Shakir, M. M., Imran M. and Iqbal K. 2014. Comparative efficacy of some neonicotinoids and traditional insecticides on sucking insect pests and thei natural enemies on bt-121 cotton crop. The Journal of Animal \& Plant Sciences, 24(2): 660-663

Amjad, Muhammad., Bashir. Muhammad Hamid., Afzal, Muhammad and Khan, Muhammad Ahsan 2009. Efficacy of Some Insecticides Against Whitefly (Bemisia tabaci Genn.) Infesting Cotton under Field Conditions. Pak. j. life soc. sci. 7(2): 140- 143

Anonymous 2006. Report On Research Review Sub-committee, AICVIP, M.P.K.V. Rahuri (Maharashtra) Ent. Veg., pp-31-32.

Babar, Tauseef Khan., Karar, Haider., Saleem, M., Saghir, Ali, Amjad Ahmad and Hameed, Asifa 2013. Comparative efficacy of various insecticides against whitefly, Bemisia tabaci (genn.) adult (homoptera: aleyrodidae) on transgenic cotton variety Bt-886. Pakistan Entomlogist, 35 (2): 99104

Bretschneider T, Benet-Buchholz J, Fischer R, Nauen R 2003. Spirodiclofen and spiromesifen a novel acaricidal and insecticidal tetronic acid derivatives with a new mode of action. Chimia 57: 697-701.

Dongarjal, R.P., Ilyas, M.D. and Shendge, S.A. 2018. Bioefficacy of newer insecticides on thrips of pomegranate. Journal of Entomology and Zoology Studies; 6(4): 1034-1036

Gupta M.P., Sandeep S, Shrivastava S.K. and Sharma S. 1997. Population build-up of some sap sucking insects on cotton in 
Madhya Pardesh. J. Insect Sci. 1997; 10:153-156.

Jadhav, V. R., Wadnerkar, D. W. and Jayekar, N. E. 2004. Fipronil 5\% SC: An effective insecticide against sucking pest of chilli (Capsicum annum L.). Pestology, 28(10): 84-87.

Kadam, D. R., Kale, V. D. and Deore, G. V. 2012. Bioefficacy of insecticides against thrips infesting pomegranate. Indian J. Pl. Prot., 40(2): 146-147.

Kadam, R. V. and Dethe, M. D. 2002. Fipronil formulation for effective control of chilli thrips, S. dorsalis (Hood). Pestology, 26(4): 36-38.

Kalyan, R. K., Saini, D. P., Urmila, P., Jambhulkar, P. and Pareek Abhishek 2012. Comparative bioefficacy of some new molecules against jassids and whitefly in cotton. The Bioscan, 7(4): 641-643, 2012

Kumar, Awaneesh., Sachan, S.K., Kumar, Sudhir and Kumar, Promish 2017. Efficacy of some novel insecticides against white fly (Bemisia tabaci Gennadius) in brinjal. Journal of Entomology and Zoology Studies, 5(3): 424-427

Kumar, V., Dhawan, A. K. and Singh G. 2013. Bio-efficacy of fipronil (Jump 80 WG) against Thrips tabaci Lindeman on cotton. Journal of Insect Science, 26 (1):126-129.

Pokharkar, D. S., Kale, I. K. and Pawar, D. B. 2011. Management of onion thrips (Thrips tabaci L.) through varietal screening and newer insecticides. J. Agric. Res. Technol., 36(2): 237-240.

Sahito, Hakim Ali., Shah, Zafar Hussain., Ruk, Majeeda., Shah, Muhammad Zaman and Mangrio, Wali Muhammad 2015. Toxicant Efficacy of some Insecticides against Whitefly, Bemesia tabaci under Cotton
Field Conditions at Khairpur-Sindh. Academic Journal of Entomology 8 (4): 193-200

Saner, D. V., Kabre, G. B. and Shinde, Y. A. 2013. Efficacy of newer insecticides on sucking pests in $B t$ cotton under Khandesh region of Maharashtra. International Journal of Plant Protection. 6 (2): 405-411.

Sayyed, Muhammad Basit., Saleem, A. H. and Shafqat Saeed M. A. 2011. Crossresistance, inheritance and stability of resistance to acetamiprid in cotton whitefly, Bemisia tabaci Genn (Hemiptera: Aleyrodidae). Crop Prot. 30(6): 705-712.

Shivanna, B.K., Gangadhara Naik, B., Nagaraja, R., Basavaraja, M. K., Kalleswara Swamy, C. M. and Karegowda, C. 2011. Bio efficacy of new insecticides against sucking insect pests of transgenic cotton. I.J.S.N., 2(1): 79-83.

Singh D., Shakhawat, R.P.S. and Naruka, I.S. 2013. Performance of novel insecticides for management of onion thrips (Thrips tabaci L.). Journal of Applied Horticulture. 15 (2):114-116.

Singh, R. and Jaglan, R. S. 2005. Development and management of insecticide resistance in cotton whitefly and leafhopper - a review. Agril. Rev. 26(3): 229-234.

Stanislav Trdan, Nevenka Valic, Dragan Znidarcic 2007. Field efficacy of deltamethrin in reducing damage caused by Thrips tabaci Lindeman (Thysanoptera: Thripidae) on early white cabbage. Journal of Pest Science, 80:217

Varghese, Thania Sara and Mathew Thomas Biju, 2013. Bio-efficacy and safety evaluation of newer insecticides and acaricides against chilli thrips and mites. Journal of Tropical Agriculture, 51 (1-2): 111-115.

\section{How to cite this article:}

Bhavna Verma, Nikki Bhardwaj, S.B. Singh and Manorama Sharma. 2019. Alternation of Insecticidal Sprays for the Management of Thrips (Thrips tabaci Lindeman) and Whitefly (Bemisia tabaci Gennadius) Pest of Bt Cotton in Malwa Region of Madhya Pradesh. Int.J.Curr.Microbiol.App.Sci. 8(02): 2293-2300. doi: https://doi.org/10.20546/ijcmas.2019.802.267 